\title{
Hospital structure elements demarcating (in)visibilities of institutional violence against children
}

\author{
Elementos da estrutura hospitalar demarcando (in)visibilidades da violência institucional à criança
}

Elementos de la estructura hospitalaria que demarcan (in)visibilidades de la violencia institucional contra la niñez

\section{Ana Carla Petersen de Oliveira Santos ORCID: 0000-0002-9816-1560 \\ Climene Laura de Camargo' ORCID: 0000-0002-4880-3916}

Mara Ambrosina de Oliveira Vargas" ORCID: 0000-0003-4721-4260

'Universidade Federal da Bahia. Salvador, Bahia, Brazil. "Universidade Federal de Santa Catarina. Florianópolis, Santa Catarina, Brazil.

How to cite this article: Santos ACPO, Camargo CL, Vargas MAO. Hospital structure elements demarcating (in)visibilities of institutional violence against children. Rev Bras Enferm. 2022;75(Suppl 2):e20200785. https://doi.org/10.1590/0034-7167-2020-0785

Corresponding author: Ana Carla Petersen de Oliveira Santos E-mail: acarlapetersen@hotmail.com

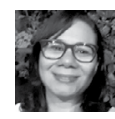

EDITOR IN CHIEF: Antonio José de Almeida Filho ASSOCIATE EDITOR: Maria Saraiva

Submission: 08-20-2020 Approval: 09-05-2021

\begin{abstract}
Objectives: to analyze the hospital structure elements that demarcate (in)visibilities of institutional violence in hospitalized children. Methods: this is a descriptive-exploratory qualitative study that used approaches with Foucault's thinking. Ten companions and 39 healthcare professionals from a university hospital in Salvador, Bahia participated. Data collection took place from November 2018 to June 2019 through semi-structured interviews. The discourse analysis method was used. The study was approved by the Institutional Review Board. Results: institutional violence was understood in the violations and invisibilities of the structure of health services through the problems: in infrastructure (physical structure, lack of human and material resources, scrapping of equipment); administrative and management; pilgrimage. Final Considerations: it is necessary to realize the invisibilities of the infrastructure to act in confronting institutional violence to hospitalized children.

Descriptors: Structure; Hospital; Violence; Institutional; Child.
\end{abstract}

\section{RESUMO}

Objetivos: analisar os elementos da estrutura hospitalar que demarcam (in)visibilidades da violência institucional em crianças hospitalizadas. Métodos: estudo qualitativo descritivoexploratório, que utilizou aproximações com o pensamento foucaultiano. Participaram 10 acompanhantes e 39 profissionais de saúde de um hospital universitário em Salvador, Bahia. A coleta de dados ocorreu de novembro 2018 a junho 2019 através de entrevista semiestruturada. Utilizou-se o método da análise do discurso. $O$ estudo foi aprovado pelo Comitê de Ética em Pesquisa. Resultados: a violência institucional foi compreendida nas violações e invisibilidades da estrutura dos serviços de saúde através dos problemas: na infraestrutura (estrutura física, falta de recursos humanos e materiais, sucateamento de equipamentos); administrativos e de gestão; peregrinação. Considerações Finais: é necessário perceber as invisibilidades da infraestrutura para atuar no enfrentamento da violência institucional à criança hospitalizada.

Descritores: Estrutura; Hospitalar; Violência; Institucional; Criança.

\section{RESUMEN}

Objetivos: analizar los elementos de la estructura hospitalaria que demarcan (in) visibilidades de la violencia institucional en niños hospitalizados. Métodos: estudio cualitativo descriptivoexploratorio, que utilizó enfoques con el pensamiento de Foucault. Participaron diez acompañantes y 39 profesionales de la salud de un hospital universitario de Salvador, Bahía. La recolección de datos se realizó desde noviembre de 2018 hasta junio de 2019 a través de entrevistas semiestructuradas. Se utilizó el método de análisis del discurso. El estudio fue aprobado por el Comité de Ética en Investigación. Resultados: la violencia institucional se entendió en las violaciones e invisibilidades de la estructura de los servicios de salud a través de los problemas: infraestructura (estructura física, falta de recursos humanos y materiales, desguace de equipos); administrativo y gerencial; peregrinaje. Consideraciones Finales: es necesario darse cuenta de las invisibilidades de la infraestructura para actuar en el enfrentamiento de la violencia institucional contra los niños hospitalizados. Descriptores: Estructura; Hospitalaria; Violencia; Institucional; Niño. 


\section{INTRODUCTION}

Institutional violence (IV) is defined as that exercised in/by institutions providing services in the area of health, justice and education, which includes an action or omission, from the lack of access to the poor quality of these services, which has as its main cause the asymmetrical power relations between users and professionals ${ }^{(1)}$. Although little explored, discussions about IV have advanced. This is partly due to the concern of the United Nations, which, in 2015, instituted peace, justice and effective institutions as one of the millennium goals, in the hope of reducing by 2030 all forms of violence within institutions, making them effective, accountable and transparent ${ }^{(2)}$.

In practice, IV in health services can be evidenced by the violation of patients' rights, which range from the pilgrimage of users to various services in search of care, even abuses and prohibitions during the hospitalization period that infringe patients' rights, causing abuse to users motivated by negligence, physical, symbolic or psychological violence practiced in the institutional context $^{(3-4)}$. IV can also be recognized by the inadequacy of the physical structure of health services, as well as the rigid and inflexible imposition of institutional norms and routines. Problems related to poor quality of care can also be found due to the reduced number of professionals and material resources ${ }^{(5)}$.

When the victim is a child, IV becomes more serious, considering the condition of vulnerability inherent in age, due to cognitive and motor immaturity, causing consequences that impact on child development, since the hospitalization process in this age group by itself is a stress factor ${ }^{(6)}$. According to the Child and Adolescent Statute (ECA - Estatuto da Criança e do Adolescente), children must have full access to lines of care aimed at their health through the Unified Health System (SUS - Sistema Único de Saúde), based on equity in access to these services ${ }^{(7)}$. Resolution 41 of the Brazilian National Council for the Rights of Children and Adolescents (CONANDA - Conselho Nacional dos Direitos da Criança e do Adolescente) establishes that both have the right to be hospitalized when necessary for their treatment and must receive all therapeutic resources available for cure, rehabilitation and secondary or tertiary prevention ${ }^{(8)}$.

However, despite health policies and laws enacting directive guidelines to ensure child care in health services, the concern with child care is mainly supported by the significant reduction in pediatric hospital beds, caused by the underfunding of SUS since its creation. According to the Brazilian Society of Pediatrics, 15,900 pediatric hospital beds have been closed in Brazil in the last 10 years, causing, in part, children's pilgrimage to health services. Other problems can also be added, such as lack of human and material resources to assist these users. Such an obstacle becomes worrisome as it can trigger care failures, compromising individuals' health and increasing the length of hospital stay ${ }^{(9-10)}$.

Promulgation of Organic Law 8080/90, which instituted SUS, establishes universality, integrality and equity as principles ${ }^{(7)}$; however, the presence of pilgrimage, lack of access, poor quality and omission of services reveal the presence of IV in these spaces. With the violation of users' rights in the health system, the State and the institutional machine become its potential offenders.

However, the little emphasis given to discussions related to IV in children can be considered as a reflection of the way they were historically represented in society, as a simple small adult, which makes it difficult to understand them as a subject of law in development process ${ }^{(11)}$. In view of these considerations, there is a need to deepen the discussions related to structural problems and the practice of IV to children in health services, considering both the aspect of violation and the invisibility with which it is treated in these institutions.

For Foucault, medicine developed from a biopolitical strategy, in which it was necessary to adopt measures to raise the population's health condition considered as labor ${ }^{(12)}$. The analysis of biopolitics, through the governmental reason, is intensely related to economic convictions, where the government of bodies is measured by the economic benefit, which often collides with meeting the basic needs of individuals, particularly with regard to the implementation of rights. Thus, the lack of resources to assist the population makes it impossible for health institutions to provide universal, egalitarian and comprehensive care to users ${ }^{(7)}$ (especially the most vulnerable), thus leading to the development of IV in these instances. Thus, this study has as a guiding question: how do structural problems in health services demarcate the presence of IV in hospitalized children?

\section{OBJECTIVES}

To analyze the hospital structure elements that demarcate (in)visibilities of institutional violence in hospitalized children.

\section{METHODS}

\section{Ethical aspects}

This research was submitted to the Institutional Review Board, via Plataforma Brasil, starting after its approval. The research took place within the ethical standards of Resolution 466/12 of the Brazilian National Health Council (Conselho Nacional de Saúde) ${ }^{(13)}$.

\section{Theoretical-methodological framework}

The research sought approximations with Michel Foucault's thought through discourse analysis. For Foucault, discourses are joint forms of utterances that belong essentially to the same discursive form, being related to institutional principles and rules that permeate speakers and their speech, so it is necessary to investigate such utterances to understand the power games behind these.

Discourse analysis seeks to unveil the institutional nature of the discursive order; therefore, paying attention to the singularities of the events and their discontinuities, in order to extract speeches' mobile, strategic and political character, it is urgent to express the elements of knowledge/power of the events ${ }^{(14)}$. Foucault also argues that through the speech considered as true we are judged, condemned, classified, forced to take on tasks and a way of living or dying; therefore, analyzing the speeches becomes an important key in understanding the events that occur in society, especially within institutions ${ }^{(12)}$.

\section{Study design}

This is an exploratory descriptive qualitative research. 


\section{Methodological procedures}

\section{Study setting}

The research took place in a 26-bed pediatric inpatient unit assisting children aged 3 months to 14 years at a large general university hospital in Salvador, Bahia.

\section{Data source}

Participants were the companions of hospitalized children and healthcare professionals who worked in that pediatric unit. Among the criteria to participate in the research were considered: companions, over 18 years of age and having been accompanying the child for more than 7 days (since this period of greater contact with the hospital environment, it became opportune for various situations related to IV to emerge), healthcare professionals, have been working in pediatrics for over two years, for the same reason.

Data were collected through interviews, which took place in the pediatric unit, without objections or difficulties, conducted by the main researcher. Participants, both companions and professionals, were chosen for convenience (those who were in the unit and agreed to participate in the research). The average interview time in the group of healthcare professionals was 11 minutes, while in the group of companions, 28 minutes. The interviews were carried out after consent of the interviewees and signing of the Informed Consent Form pursuant to Resolution 466/2012 $2^{(13)}$.

\section{Data collection and organization}

Data collection followed based on COnsolidated criteria for REporting Qualitative research (COREQ). The interview was used, guided by a semi-structured script, previously validated by a team of researchers. The closed-ended questions contained information about individuals'sociodemographic profile, while the open-ended ones, the following guiding questions for the companions: how has the care of your child been in this hospital? Did you or your child have any problems during hospitalization? Which? (This question was asked in a broad way as it was understood that participants would be free to report events and experiences that could bring out IV elements in the speeches). Then, the interviewer presented a brief explanation about IV and its characteristics to the interviewee and ended with the question: do you identify any situation that characterizes as IV during your child's hospitalization? For the professionals, the questions were: in your opinion, according to your professional experience, what problems does a child face during the hospitalization period? (in the same way it was explained to them about IV and its characteristics). Subsequently, the following question was asked: do you identify any type of IV in the hospitalized child? Which one or which ones? The interviews were recorded and transcribed in full.

IV elements were identified in the speeches according to IV characterization established by the Ministry of Health ${ }^{(4)}$. Data collection was completed when there was a saturation of data from the interviews of both groups, as they had obtained sufficient density to analyze the proposed theme. To ensure anonymity, participants' names were identified: companion, by numbers; professionals, by professional category and number.

\section{Data analysis}

The analytical procedures followed the steps of discourse analysis. Therefore, after exhaustive reading, the concepts were unfrozen, disarticulated and then proceeded with the analysis and establishment of uptake relationships. From these relationships, a new emerged, which through associations in discursive utterances, composed the three discursive formations that guided the research results.

\section{RESULTS}

Ten companions and 39 healthcare professionals participated in the study. According to companions' sociodemographic profile, all were female, mothers of hospitalized children, aged between 19 and 45 years, most with high school education and income of up to 01 minimum wage. The healthcare professionals belonged to the categories: social worker (01), nurse (06), pharmacist (02), physiotherapist (05), speech therapist (01) physician (07), nutritionist (05), psychologist (01), health technician nursing (11). In this group, all were female, aged between 27 and 62 years, average income of 5 to 10 minimum wages, most had between 6 to 10 years of experience in pediatrics.

With the purpose of analyzing how the hospital structure elements demarcate IV in hospitalized children, the results were presented in three discursive formations: infrastructure problems, characterized by inadequacies in the physical structure, insufficient human resources, scrapping and/or lack of equipment, furniture and lack of materials; problems in service management, made visible through administrative, bureaucratic and management obstacles; and pilgrimage, which supports the discourse of the exhaustive search for health care in various services.

Among the problems in infrastructure, inadequate physical structure emerged as an important generator of discomfort for the child and family, evidenced by the lack of spaces and/or inadequacy of those that already exist, discrepancy between the accommodation provided and children's and families' needs:

In ward 7, children do not have a toilet. It's a sink that the mother has to put the child on top and then she does there. It's complicated. (NURSING TECHNICIAN 08)

Sometimes it is a child too big to be in a crib, she has to stay in the crib because there is no bed available. (NURSING TECHNICIAN 09)

Family comfort is very precarious. Sometimes there's only one chair. Who stays here longer does not have a laundry to wash their clothes, does not have a closet to store their belongings. Little value is given to this issue of comfort. (PHYSICIAN 05)

The lack of space for playful and recreational activities with child and family, the absence of the hospital class, the little usefulness of the toy library and the signaling that the environment is not appropriate for performing recreational activities, are discourses that are supported from participants' perspective. However, there 
is a gap in this discourse between the companions, perhaps because it is not even in the order of the visible/sayable:

There was kindergarten, it is the child's right. We lost kindergarten, storytelling and occupational therapy. Occupational therapy is of fundamental importance, both for mothers and children. The child needs to be stimulated within the hospital environment. We stayed a time without the toy library. The leisure space for the child is a priority space. (NUTRITIONIST 05)

But facility discomfort, sensations of isolation and imprisonment were frequent statements among the companions:

We stay because we need to, but there are times that give an agony in the head, because being stuck all the time in a room is tiring. Inside the room between 4 walls, you stay because it is necessary, but it is uncomfortable. (COMPANION 08)

The problem of insufficient human resources in child care also emerged, which determines failures in care and contributes to the occurrence of errors, poor quality of care and even worsening of children's condition:

It is inhumane for a nurse to have 27 patients, as it happens. Is this nurse able to adequately care for these patients? (NURSE 05)

The scrapping of equipment and furniture is a discourse legitimized in the statements of professionals and companions as an intervening factor in IV to hospitalized children:

The cribs are old. Sometimes the child is sleeping; and when we lower the crib rail, it makes a noise, and the child wakes up scared. (NURSING TECHNICIAN 06)

The other day there was no elevator, surgery and examination were suspended, so this traumatizes not only the child, but also the companion. (NURSING TECHNICIAN 05)

Professionals and companions deliver discourses both of the lack of materials and equipment, as well as the offer of materials that do not contemplate the specificity of care to children. This deficiency causes problems such as postponement of procedures, examinations and impacts on the increase in hospitalization time, therefore, on risks of worsening of children's clinical condition:

We have five patients who need a medication and need to be monitored at the time of infusion, but we only have two monitors or three. What about the other two children, how are they? (NURSE 05)

She has an endoscopy also to do with ligation that I'm not able to score here because it's out of material. (COMPANION 07)

Although in public health policies child health care services are presented as a right, the speeches of professionals and companions reveal the existence of problems related to management, characterized by slowness and delay in administrative processes, difficulty in dealing with bureaucratic situations, as well as leadership decisions that compromise the care and care of users and their families:
The bureaucracy's problem to give comfort to your child. When I wanted to donate an air conditioner, I couldn't, because there are legal procedures. I wanted to buy the part, I can't, because it's already on bidding. I got a technician to fix it, but the hospital said I can't either, because it has to be a person from here, because it's overturned. They do not make things easier and on account of a play let a child suffer in a room isolated for days. Administration is totally flawed! (COMPANION 10)

Let the management here let us wear colorful clothes. The staff bought the clothes, but they do not allow. Let us parade with more joy, to be able to show that this is not an environment of suffering. (NURSING TECHNICIAN 07)

On the other hand, the discursive formation of pilgrimage overlaps as a serious problem, responsible for delays in the care provided to patients. In this study, participants support statements that express the delay in diagnosis and beginning of treatment:

It is common here at the institution to receive patients who come from the third institution on a pilgrimage, because there is no exam that needs to be taken from the first institution. She is admitted to an ECU, goes to a tertiary hospital, but in this hospital the child needs an exam that he does not have, then he is transferred to another hospital. This is the experience of daily people. (PHYSICIAN 01)

We have a child hospitalized now who will probably have to undergo an enucleation of the eye because he had a late diagnosis of a disease that could have been diagnosed back there and had saved him from having the enucleation, only doing local treatment. The worst violence of child health is delay in diagnosis, pilgrimage. (PHYSICIAN 02)

We lost our emergency and that limits the patient. We have patients, we are a reference hospital for various specialties, and sometimes these patients sharpen and have nowhere to go, end up going to the most distant institutions and then come here. The pediatric emergency, but closed for reform and no longer opened. (PHYSICIAN 04)

\section{DISCUSSION}

The study showed that IV against children is also linked to discourses that support the commitment of the structure of health services. IV situations to children are manifested by the absence of physical spaces, insufficient human resources, scrapped furniture, equipment and lack of materials. These conditions may be linked to the crisis of underfunding of SUS, but they also indicate an incipient attention from local management when disregarding the needs and peculiarities of health care for children.

In the discursive formation that activates discourses of lack of management attention to children's needs (as evidenced by the inexistence of the hospital class and the pedagogical professional in the pediatric inpatient unit), it can be noted a child health care idealized through public policies that advocate educational services in hospital environments (hospital classes) with the objective of helping the child to develop cognitive capacity, meeting their learning needs, minimizing the stressful effects of the hospital environment ${ }^{(15-17)}$. However, it is the very visibility of this idealized possibility that points to the finding 
of the absence of this service in practice, revealing a context of health care for children, in no way different from the context of health care for adults, centered on actions related to treatment and cure of diseases, without considering children's needs and the specifics of their development.

Thus, the discourse of violations and invisibilities in the structure where pediatric care takes place sustains the profound influence of the concept of the hospital as a place destined only for patients' cure and treatment, characteristic of a health model centered on the biophysician view, emerging in the $18^{\text {th }}$ century. For Foucault ${ }^{(12)}$, medicine was established for healing and used discipline and supervision to exercise control over bodies. The therapy consisted of suppressing the disease until it was reduced to non-existence, leading to the assumption that the various forms of physician knowledge constitute positive notions of health and normality, in which the definition of the model man is described as a non-sick man. In this conception of care, there was no space to think about issues related to health promotion and child development; thus, it is important to consider that the inexistence of children's rights, such as the functioning of the hospital class, may be rooted in such conceptions.

The perspective of health promotion is to generate well-being and is based on the set of values that encompass life, health, equity, community participation and individual development for the establishment of healthy public policies ${ }^{(18)}$. However, the discourses that are operationalized in participants' statements point to some gaps between health policies and effective child care. Therefore, infants represent yet another product controlled by a health system that seeks to govern the clinic by evaluating the results of measurements and the objectives of previously established clinical practice and treatment, regardless of the specific needs of each one ${ }^{(19)}$.

A survey carried out in Italy revealed that professionals confirmed that the right to continue school education is one of the least respected in pediatric units, being more often guaranteed in pediatric hospitals than in general hospitals. In Austria, it was found that this same right is established in almost all child psychiatric inpatient units ${ }^{(20-21)}$. In Brazil, there is also evidence of problems related to the absence of a hospital class and difficulty in acquiring materials to keep the toy library functioning, which demonstrates that the education of hospitalized children has not been valued in health services ${ }^{(10)}$

Despite Resolution 41 of 13 October 1995 regulates the right of hospitalized children and adolescents, emphasizing that children have the right to have their school curriculum monitored during their stay in the hospital. In this study, participants reiterate statements that this is not guaranteed ${ }^{(8)}$. The service's attitude of failure to provide the conditions for the child to receive school monitoring reveals itself as a violation of rights, which can be characterized as a situation of IV.

Another situation, which is also located in the analysis carried out so far, deals with the inadequacy of space for accommodation of companions. In the statements, the problem emerges that although the health service offers space for the family to stay with the child within 24 hours, the conditions of this environment were precarious, putting the safety of everyone involved at risk. The right to a companion, despite being one of the most respected by health institutions, is opposed to the precarious conditions in which they remain, which can increase the family's and children's stress.

The presence of a companion is beneficial because, in addition to minimizing children' psychological distress, it also helps in the early detection of risks during the hospitalization period ${ }^{(1)}$. In the $E C A$, it is indicated that it is the obligation of health establishments to provide conditions, when the child is hospitalized, for the full-time stay of a parent or guardian ${ }^{(7)}$; however, such conditions become a paradox: to remain in order to enable the children to adapt better and minimize suffering; or remain in completely inadequate conditions, which triggers other forms of stress and even the family member becoming ill.

Other infrastructure problems present in the statements confirm the lack of professionals and specific material, which causes serious damage to child care. This discourse is supported by research that confirms the deficit of human, material and drug resources in health services, which directly affects the quality of care and determines the occurrence of another type of IV, pilgrimage ${ }^{(5,22-25)}$.

The discursive regularity of the problem of scarcity in participants' statements goes far beyond quantitative logic. In this sense, what determines the fair redistribution of resources when they are already scarce? It can be said that the principles of distributive justice should define how scarce resources need to be allocated. Scarcity, on the other hand, is a phenomenon related to the satisfaction of public needs, which can be evidenced by the lack of specialized personnel, equipment and other inputs ${ }^{(26)}$. Therefore, in order to allocate resources, it is necessary to consider how much to make available and to whom to assist, as there is no single criterion that can guide these adjustments, therefore, allocation decisions tend to be essentially political and local. In this way, when there are severe budget restrictions, people can become effective victims and the State will have done little or nothing about this sanction ${ }^{(27)}$.

When we discuss rights, it is necessary to consider their impossibility or invisibility. Considering the unfeasible rights implies questioning that for them to materialize, it is necessary to have a structure to implement and supervise them, which makes it subject to the State's mode of economic production ${ }^{(27)}$. For Foucault, a government only acts when there is interest. Even a punishment must be applied considering the interests: is there an interest in punishing? Are you interested in begging? How much will it cost to reeducate? Discourses are governed by interests ${ }^{(12)}$.

Evaluating rights as invisible, suggests reflecting that it is from the environment conditions that needs emerge. Even if the theory shows and considers that health promotion actions have an impact, that public policies regulate professional qualification in favor of more effective care, visibility would be given by being aware of specific needs of physical structure and of human resources, as it is necessary to know to recognize. However, the speeches reproduced by professionals and companions elucidate that during children's hospitalization, treatment and care occur, but without valuing children's and their families' needs. Therefore, it is problematic to use a discourse of accountability of individuals, institutional structure, professionals, to the detriment of an entire process that needs to be made visible from the political, economic and cultural point of view. In short, according to Foucault, the State's objective in implementing rights is not to 
provide a legal framework to respect the fundamental rights of individuals, but rather equipping its policy on what happens in society, the market and the economy so that the limitation of its power is not guided by the freedoms of individuals, but by the economic analysis of what it will need to respect ${ }^{(12)}$.

According to Foucault, medicine is a biopolitical strategy, which the State uses to control the population. Therefore, biopolitics is used along the lines of liberalism to ensure that social utility and economic benefit are used in favor of the State and not individuals, especially those with limited representation ${ }^{(12)}$. Other studies reveal that the impact of economic policies on health services generates inequality and stratification of care, as actions are conditioned to economic indicators and not to human rights, which affects the autonomy of people, especially the most vulnerable ${ }^{(28-29)}$. According to the Convention on the Rights of the Child (1990) ${ }^{(30)}$, children need special protection and care, but it is evident to consider that the State and local management have failed, as they do not supply or monitor the fair distribution of resources to ensure the quality of service to it.

In turn, the pilgrimage to health services is seen as a type of structural violence, as it reveals the inequalities and social injustices reproduced in institutions, in addition to indicating the presence of other types of inequities committed in health care services $^{(31)}$. Pilgrimage can occur due to: failure in the structure and organization of service networks; insufficient logistical and transport system; low resolution; problems in the reception of users; reduced number of pediatric services and healthcare professionals, as well as the fragmentation of work between health teams ${ }^{(23-24,32)}$. This phenomenon can become more intense when users belong to vulnerable or neglected populations, such as children with special needs, quilombolas (Common designation for refugee slaves in quilombos, or descendants of black slaves whose ancestors during the period of slavery fled from sugar cane plantations, farms and small properties), indigenous people and rural communities, which reflects the influence of social and economic determinants in the search for health care $^{(33-34)}$.

In spite of this, pilgrimage contributes to the increase in mortality rates, because while the user seeks care in health services, his clinical condition worsens, increasing the risk of death. This can be seen when we verify research results in the obstetric field, in which pilgrimage increased the risk of infant death three times more ${ }^{(34-35)}$. Pilgrimage takes place at different levels of the service network, from primary care to high complexity, being present in several countries ${ }^{(36)}$. Furthermore, the act of pilgrimage demonstrates that, although some services have technological resources, the lack of assistance occurs due to unpreparedness and difficulties in the organization and care of patients ${ }^{(35)}$.

For Foucaul $\mathbf{t}^{(37)}$, the violent character of power practices derives from the political rationality behind it. Violence on pilgrimages is, therefore, a manifestation of the political rationality of the State's political economic system due to the political-administrative mismatch that results in deprivation and difficulties in the search for health care. This distortion in health care is violent, as the institution reproduces its inequities, demonstrating that there is still great difficulty in developing principles of integrality and equity.

According to Foucault's thinking, the presence of economic rationality in the speeches is compatible with the biopolitical strategy used in the security device. That is, the security device is a power technology used to control populations through demographic data, in order to control government reason. In this study, pilgrimage, sustained as a discourse that announces a recurrent situation, is an issue that demonstrates little or no concern of management with expanding the provision of services to children, possibly due to the lower representation it has with regard to care in the health network. Thus, the concept of the invisibility of children in the health service remains, which becomes inconsistent, as children's demands are numerous and growing.

Paradoxically, despite the bill of rights for users of health services emphasizes that "every citizen has the right to orderly and organized access to health systems" ${ }^{\prime \prime(7)}$ and the ECA guarantee children full access to lines of care through SUS, what is perceived is the view that users who receive health care are considered privileged. Such evidence was found in a survey that sought to highlight the users' perception of accessibility in health services, in which they felt the professionals treating them as a bunch of needy people and the assistance provided, a charity ${ }^{(38)}$.

Problems related to management revealed poor quality of health care for children and their families. What is most expressed in the statements is the standardization of services consisting of strict rules and routines and the presence of failures in management decision-making. In this sense, a study indicates that the standardization of services is often a contradiction in terms of the importance of implementing a care plan that respects the differences existing in the various centers ${ }^{(39)}$. Thus, the application of strict rules and the overvaluation of bureaucracy prevented children from receiving adequate or minimally adequate care.

The principle of comprehensiveness is considered as an articulated and continuous set of preventive or curative, collective or individual actions that need to exist at all levels of complexity of the system ${ }^{(10)}$. However, in the discursive statements, it could be analyzed that care is often fragmented, committed much more to the norm than to individuals' rights. An example of this was the determination that the nursing staff wear only the white uniform. This requirement is nothing more than the imposition of rules reproduced in health services originated in discourses that propagate signs of control and authority produced amid a discursive dynamic based on discipline, which comes to oppose important principles of practice that value humanized care for children.

For Foucault, discipline within hospitals is based on the composition of well-defined strategies for control of bodies, time, space, norms and training ${ }^{(12)}$. Thus, the data from this research show the permanence of elements related to strict norms and rules imposed by hospital institutions, leading children and their families to experience deprivation and violence.

Administrative failures, made visible by the research participants, show IV by noting the invisibilities of children's and their families'needs. For Foucault, "the rule is the calculated pleasure of obstinacy"(37), through it, domination is allowed to occur. Thus, the universe of rules satisfies violence, as these are empty, they only assist those who take possession of them. In this study, professionals and users are immersed in the same logic of discourses that convey a universe of rules, however it is necessary to consider that such rules, in many situations, prevailed to the detriment of 
users' rights. Furthermore, it was possible to notice the existence of escape zones (visibilities) and spaces of resistance in the speeches of professionals and companions, but it is still necessary to ask: how can adjustments, changes and improvements that seek to capture the difference in favor of quality of care?

\section{Study limitations}

In the present study, even though it has carried out a productive number of interviews with professionals and companions, the fact that it was carried out in a university hospital in a northeastern state is considered a limitation, thus obtaining a restricted representation.

\section{Contributions to nursing}

This study fills an important gap in research involving IV in health services and child care. By recognizing the invisibility of
IV to children in the hospital structure, nursing can understand and act in the adoption of measures that will minimize this problem, allowing care to occur in a safer and more humane way for children and their families.

\section{FINAL CONSIDERATIONS}

This study presented and discussed the structural elements related to IV in the care environment for hospitalized children, evidenced by the problems of infrastructure, management and pilgrimage. The invisibilities that delimit IV to the hospitalized child were identified through violations of children's rights, which affect the inadequacies of the hospital structure. Foucault's thought contributed to a better understanding of the gear and disposition of power games (biopolitical strategy and discipline) behind these invisibilities. It is urgent to consider the need to expand discussions about IV in hospitals, as a way to offer quality care to children so that the service is not a producer of violence, but an ally in its fight.

\section{REFERENCES}

1. Fleury S, Bicudo V, Rangel G. Reacciones a la violencia institucional: estrategias de los pacientes frente al contraderecho a la salud en Brasil. Salud Colect [Internet]. 2013[cited 2017 Feb 05];9(1):11-25. Available from: https://www.scielosp.org/pdf/scol/2013.v9n1/11-25/es

2. Organização das Nações Unidas. 17 objetivos para transformar o mundo [Internet]. Rio de Janeiro: UNIC Rio; 2015 [cited 2017 Feb 05]. Available from: https://unicrio.org.br/pos2015/

3. Souza $A B$, Silva $L C$, Alves RN, Alarcão $A C J$. Fatores associados à ocorrência de violência obstétrica institucional: uma revisão integrativa da literatura. Rev Cienc Med. 2016;25(3):115-28. https://doi.org/10.24220/2318-0897v25n3a3641

4. Ministério da Saúde (BR). Violência intrafamiliar: orientações para prática em serviço [Internet]. Brasília, DF: MS; 2002[cited 2017 Feb 05]. (Série cadernos de atenção básica, nº 8; Série A normas e manuais técnicos, n 131). Available from: http://bvsms.saude.gov.br/bvs/ publicacoes/cd05_19.pdf

5. Marrero L, Brüggemann OM. Institutional violence during the parturition process in Brazil: integrative review. Rev Bras Enferm. 2018;71(3):1152-61. https://doi.org/10.1590/0034-7167-2017-0238

6. Schatkoski AM, Wegner W, Algeri S, Pedro ENR. Safety and protection for hospitalized children: literature review. Rev Latino-Am Enfermagem. 2009;17(3):410-6. https://doi.org/10.1590/S0104-11692009000300020

7. Presidência da República (BR). Lei n 8.069, de 13 de julho de 1990. Dispõe sobre o Estatuto da Criança e do Adolescente e dá outras providências [Internet]. Brasília, DF: PR; 1990[cited 2018 Jun 24]. Available from: http://www.planalto.gov.br/ccivil_03/Leis//8069.htm

8. Conselho Nacional dos Direitos da Criança e do Adolescente (BR). Resolução no 41 de 13 outubro de 1995 [Internet]. Brasília, DF: 1995[cited 2018 Jun 24]. Available from: https://www.sbp.com.br/fileadmin/user_upload/img/documentos/doc_criancas_hosp.pdf

9. Sociedade Brasileira de Pediatria. 15,9 mil leitos de internação pediátrica foram fechados no Brasil, nos últimos nove anos [Internet]. Rio de Janeiro: SBP; 2020[cited 2020 Feb 20]. Available from: https://www.sbp.com.br/imprensa/detalhe/ nid/159-mil-leitos-de-internacao-pediatrica-foram-fechados-no-brasil-nos-ultimos-nove-anos/

10. Souza RR, Vieira MG, Lima Jr CJF. The integral child health care network in the Federal District, Brazil. Cienc Saude Colet. 2019;24(6):2075-84. https://doi.org/10.1590/1413-81232018246.09512019

11. Ariès P. História social da criança e da família. 2a ed. Rio de Janeiro: Guanabara; 1986.

12. Foucault M. Microfísica do poder. Rio de Janeiro: Edições Graal; 1979.

13. Ministério da Saúde (BR). Resolução $n^{\circ}$ 466/12, de 12 de dezembro de 2012. Dispõe sobre pesquisa envolvendo seres humanos [Internet]. Brasília, DF: MS; 2012[cited 2017 Jun 08]. Available from: https://bvsms.saude.gov.br/bvs/saudelegis/cns/2013/res0466_12_12_2012.html

14. Almeida DB, Santos NVC, (Orgs.). Foucault como referencial teórico metodológico na produção científica de enfermeiras. Feira de Santana: Editora Zarte; 2020.

15. Medeiros JLG. Atendimento educacional em ambiente hospitalar: princípios pedagógicos. Rev Educ. 2020;45:e14. https://doi. org/10.5902/19846444

16. Boles JC, Winsor DL, Mandrell B, Gattuso J, West N, Leigh L, et al. Student/patient: the school perceptions of children with cancer. Educ Stud. 2017;43(5);549-66. https://doi.org/10.1080/03055698.2017.1312288 
17. Tsimicalis A, Genest L, Stevens B, Ungar WJ, Barr R. The impact of a childhood cancer diagnosis on the children and siblings' school attendance, performance, and activities: a qualitative descriptive study. J Pediatr Oncol Nurs. 2018;35(2):118-31. https://doi. org/10.1177/1043454217741875

18. Roy MJ. The assets-based approach: furthering a neoliberal agenda or rediscovering the old public health?: a critical examination of practitioner discourses. Crit Public Health. 2017;27(4):455-64. https://doi.org/10.1080/09581596.2016.1249826

19. Molina-Mula J, Gallo-Estrada J, Perelló-Campaner C. Impact of interprofessional relationships from nurses' perspective on the decisionmaking capacity of patients in a clinical setting. Int J Environ Res Public Health. 2017;15(1):49. https://doi.org/10.3390/ijerph15010049

20. Bisogni S, Aringhieri C, McGreevy K, Olivini N, Gonzalez Lopez JR, Ciofi D, et al. Real implementation of the rights of sick children in Italian pediatric units: a descriptive study based on nurses' perceptions. BMC Med Ethics. 2015;16:33. https://doi.org/10.1186/s12910-015-0021-0

21. Berger $\mathrm{E}$, Paar C. Preventive human rights monitoring in child and adolescent psychiatry and welfare institutions. Neuropsychiat. 2017;31(3):133-43. https://doi.org/10.1007/s40211-017-0244-z

22. Moreira GAR, Vieira LJES, Cavalcanti LF, Silva RM, Feitoza AR Manifestations of institutional violence in the context of health care for women in situations of sexual violence. Saude Soc. 2020;29(1):e180895. https://doi.org/10.1590/S0104-12902020180895

23. Sá ACS, Silva ACSS, Góes FGB. Diagnosis of childhood and youth cancer: the families percurred path. Rev Pesqui Cuid Fundam. 2019;11(5):1180-87. https://doi.org/10.9789/2175-5361.2019.v11i5.1180-1187

24. Luz RO, Pieszak GM, Arrué AM, Gomes GC, Neves ET, Rodrigues AP. Therapeutic itinerary of families of children with special health needs. Rev Rene. 2019;20:e33937. https://doi.org/10.15253/2175-6783.20192033937

25. Kc A, Singh DR, Upadhyaya MK, Budhathoki SS, Gurung A, Målqvist M. Quality of care for maternal and newborn health in health facilities in Nepal. Matern Child Health J. 2020;24(Suppl 1):31-8. https://doi.org/10.1007/s10995-019-02846-w.

26. Amaral G. Direito, escassez e escolha: em busca de critérios jurídicos para lidar com a escassez de recursos e as decisões trágicas. Rio de Janeiro: Renovar; 2001.

27. Holmes S, Sunstein CR. El costo de los derechos: por qué la libertad depende de los impuestos. Buenos Aires: Siglo Veintiuno; 2011.

28. Camargo Plazas P. Understanding the space of nursing practice in Colombia: a critical reflection on the effects of health system reform. Nurs Inq. 2018;25(3);e12242. https://doi.org/10.1111/nin.12242

29. Sakellariou D, Rotarou ES. Access to healthcare for men and women with disabilities in the UK: secondary analysis of cross-sectional data. BMJ Open. 2017;7(8):e016614. https://doi.org/10.1136/bmjopen-2017-016614

30. Fundo de Emergência Internacional das Nações Unidas para a Infância. Convenção sobre os Direitos da Criança: Instrumento de direitos humanos mais aceito na história universal, foi ratificado por 196 países [Internet]. Genebra: 1990[cited 2017 Jun 08]. Available from: www. unicef.org/brazil/convencao-sobre-os-direitos-da-crianca

31. Macedo MCM, Bezerra Filho JG, Feitosa RFG, Moreira TMM. Fatos geradores de vítimas e perpetradores da violência. In: Bezerra Filho JG, Savioli KC, Gomes EM, Araújo ISG, (Orgs.). Acidentes e violência: uma abordagem interdisciplinar. Fortaleza: EdUECE; 2015. p. $12-37$.

32. Luz GS, Rissardo LK, Vituri LP, Meyer VA, Pelloso SM, Carvalho MDB. “Pilgriming”: experiences of family members of people with cystic fibrosis. Rev Paranaense Enferm [Internet]. 2019[cited 2017 Mar 12];2(1):23-31. Available from: http://seer.fafiman.br/index.php/REPEN/ article/view/518

33. Siqueira SMC, Jesus VS, Camargo CL. The therapeutic itinerary in urgent/emergency pediatric situations in a maroon community. Cienc Saude Colet. 2016;21(1):179-89. https://doi.org/10.1590/1413-81232015211.20472014

34. Leal MC, Bittencourt SDA, Torres RMC, Niquini RP, Souza Jr PRB. Determinants of infant mortality in the Jequitinhonha Valley and in the North and Northeast regions of Brazil. Rev Saude Publica. 2017;51:12. https://doi.org/10.1590/s1518-8787.2017051006391

35. Santos DBC, Vázquez-Ramos V, Oliveira CCC, López-Arellano O. Accesibilidad en salud: revisión sobre niños y niñas con discapacidad en Brasil-Perú- Colombia. Rev Latinoam Cienc Soc Ninez Juv. 2019;17(2);1-20. https://doi.org/10.11600/1692715x.17206

36. Galvão JR, Almeida PF, Santos AM, Bousquat A. Percursos e obstáculos na rede de atenção à saúde: trajetórias assistenciais de mulheres em região de saúde do nordeste brasileiro. Cad Saude Publica. 2019;35(12):e00004119. https://doi.org/10.1590/0102-31100004119

37. Foucault, M. The birth of biopolitics: lectures at the collège de France, 1978-1979. Basingstoke: Palgrave Macmillan; 2008.

38. Oliveira LH, Mattos RA, Souza AIS. Cidadãos peregrinos: os "usuários" do SUS e os significados de sua demanda a prontos-socorros e hospitais no contexto de um processo de reorientação do modelo assistencial. Cienc Saude Colet. 2009;14(5):1929-38. https://doi. org/10.1590/S1413-81232009000500035

39. Austin WJ. The incommensurability of nursing as a practice and the customer service model: an evolutionary threat to the discipline. Nurs Philos. 2011;12(3):158-66. https://doi.org/10.1111/j.1466-769X.2011.00492.x 